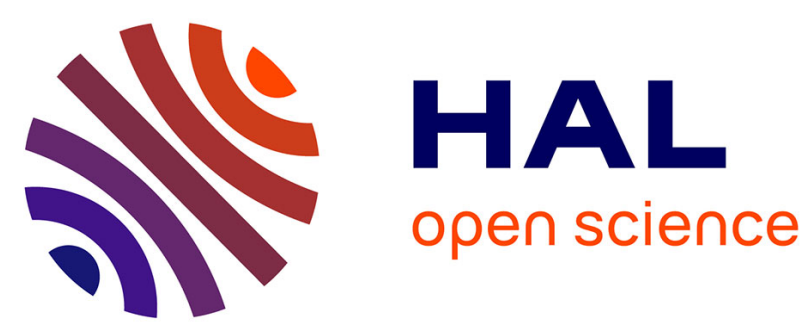

\title{
Effects of experimental warming and increased ultraviolet $B$ radiation on the Mediterranean plankton food web
}

Francesca Vidussi, Behzad Mostajir, Eric Fouilland, Emilie Le Floc'H, Jean Nouguier, Cécile Roques, Patrice Got, Delphine Thibault, Thierry Bouvier,

Marc Troussellier

\section{To cite this version:}

Francesca Vidussi, Behzad Mostajir, Eric Fouilland, Emilie Le Floc'H, Jean Nouguier, et al.. Effects of experimental warming and increased ultraviolet B radiation on the Mediterranean plankton food web. Limnology and Oceanography Bulletin, 2011, 56 (1), pp.206-218. 10.4319/lo.2011.56.1.0206 . hal-02105436

\section{HAL Id: hal-02105436 \\ https://hal.science/hal-02105436}

Submitted on 6 May 2021

HAL is a multi-disciplinary open access archive for the deposit and dissemination of scientific research documents, whether they are published or not. The documents may come from teaching and research institutions in France or abroad, or from public or private research centers.
L'archive ouverte pluridisciplinaire $\mathbf{H A L}$, est destinée au dépôt et à la diffusion de documents scientifiques de niveau recherche, publiés ou non, émanant des établissements d'enseignement et de recherche français ou étrangers, des laboratoires publics ou privés. 


\title{
Effects of experimental warming and increased ultraviolet $\mathrm{B}$ radiation on the Mediterranean plankton food web
}

\section{Francesca Vidussi,a, ${ }^{\text {B }}$ Behzad Mostajir, ${ }^{\mathrm{a}}$ Eric Fouilland,a,b Emilie Le Floc'h,a,b Jean Nouguier, ${ }^{\mathrm{a}}$ Cécile Roques, ${ }^{a}$ Patrice Got, ${ }^{a}$ Delphine Thibault-Botha, ${ }^{c}$ Thierry Bouvier, ${ }^{a}$ and Marc Trousselliera}

${ }^{a}$ Ecosystèmes Lagunaires Unité Mixte de Recherche (UMR) 5119, Centre National de la Recherche Scientifique (CNRS), Université Montpellier 2, Institut de Recherche pour le Développement (IRD), Institut français de recherche pour l'exploitation de la mer (IFREMER), Montpellier, France

b Ecosystèmes Lagunaires UMR 5119 CNRS-Université Montpellier 2- IRD-IFREMER, Station Méditerranéenne de l'environnement Littoral, Sète, France

c Laboratoire d'Océanographie Physique et Biogéochimique UMR 6535, Université Aix-Marseille, CNRS, Centre d'Océanologie de Marseille, Marseille, France

\begin{abstract}
The responses of the plankton food web to increases in temperature and ultraviolet B radiation (UVBR, 280$320 \mathrm{~nm}$ ) were experimentally investigated at a coastal Mediterranean site during spring. Eight moored mesocosms were used to compare natural plankton food web responses (control mesocosms) with three treatments simulating expected future local temperature and UVBR increases, as follows: (1) $3^{\circ} \mathrm{C}$ increase in water temperature, (2) $20 \%$ increase in incident UVBR, and (3) simultaneous $3^{\circ} \mathrm{C}$ increase in water temperature and $20 \%$ increase in incident UVBR. The plankton food web was resistant to elevated UVBR, having only moderate effects on plankton abundances and structure. In contrast, warming induced significant shifts in the plankton food web structure and function. Specifically, the abundance of protozooplankton (ciliates and flagellates) increased and the development time of copepods from nauplii to adults decreased. In the warm mesocosms, the emergence of copepod adult stages midway through the experiment resulted in a decrease in ciliates and consequently in an increase in heterotrophic flagellates. One unexpected result was that warming reduced the abundance of heterotrophic bacteria midway through the experiment. These results indicate a trophic-cascade effect under warming. The increase in adult copepods diminishes ciliates and in turn favors heterotrophic flagellates that consume bacteria. Warming also induced an increase in net oxygen production, indicating an increase in net primary production.
\end{abstract}

Understanding how organisms respond to multiple environmental stressors induced by global changes requires a better comprehension of the complex ecological mechanisms that determine these responses. Responses of organisms to a stressor can occur at the individual level as physiological acclimation (Portner and Farrell 2008) and depend on the tolerance of the species to the stressor (Vinebrooke et al. 2004). Global change can also modify community composition by promoting tolerant species and reducing sensitive ones (Vinebrooke et al. 2004). The simultaneous individual- and community-level responses of organisms to a stressor alter natural interactions among organisms, including predator-prey, competitive, mutualistic, and parasitic interactions (Davis et al. 1998; Walther et al. 2002), inducing cascading effects along the trophic food web (Weitere et al. 2008).

Previously published studies have mostly focused on the effect of one stressor at the individual level or at a single trophic level. Very few studies have been dedicated to understanding the response mechanisms of the entire aquatic plankton food web to global changes. Aquatic ecosystem functioning is based on the activity of planktonic organisms that are linked by complex trophic, competitive, and mutualistic interactions. Therefore, to evaluate the effect of climate change in aquatic environments, it is critical to understand the response of the entire plankton

\footnotetext{
*Corresponding author: francesca.vidussi@univ-montp2.fr
}

food web under global change stressors and the associated ecological mechanisms driving these responses. The response of the plankton food web to global change is complex and nonlinear. It is difficult to model and predict these complex responses based on results at the individual level and/or on a single stressor. This is because different species and trophic levels display variable sensitivities to a given stressor and because multiple stressors can interact by amplifying or suppressing the effects of other stressors (Vinebrooke et al. 2004; Christensen et al. 2006).

Recent studies investigating the effects of increased temperature on plankton communities have shown that warming modifies the magnitude and composition of the spring phytoplankton bloom (Sommer and Lengfellner 2008). By favoring microbial carbon respiration, warming may ultimately enhance $\mathrm{CO}_{2}$ release from the ocean (Vázquez-Domínguez et al. 2007). The few experiments that have incorporated several trophic levels have shown that, in general, warming adversely affects planktonic consumers while promoting producers (Beisner et al. 1997; Petchey et al. 1999; Strecker et al. 2004). In addition, shifts in the plankton community structure driven by global warming could decouple trophic interactions at higher trophic levels, modifying the temporal matching between predators and their prey (Beaugrand et al. 2003; Edwards and Richardson 2004).

Another stressor linked to global changes that can affect plankton community structure is increased ultraviolet B 
radiation (UVBR, 280-320 nm). Very few studies on the effect of UVBR have taken into account the entire plankton food web. These studies show complex responses indicating positive feedbacks of UVBR (Sommaruga 2003). Mostajir et al. (1999) have shown that UVBR reduces large planktonic microorganisms (ciliates and diatoms), resulting in accumulation of small microorganisms, such as heterotrophic flagellates, bacteria, and picophytoplankton.

Recently several studies also focused on another stressor linked to global changes, the increase of atmospheric $\mathrm{CO}_{2}$ and consequent ocean acidification, but very few have been dedicated to elucidating the effects of this stressor on the entire plankton food web (Riebesell et al. 2007) or benthic food web (Hargrave et al. 2009). It has been shown that interactions among multiple stressors due to global change better explain their combined effect on ecosystem functioning, compared with the sum of the individual effects of each stressor (Christensen et al. 2006). However, few multifactorial experiments have been dedicated to studying the effect of multiple global change stressors on aquatic ecosystems, and very few have studied the effects at several trophic levels. For example, it has been found that the effect of UVBR may be temperature dependent because temperature enhances photo-enzymatic repair (Williamson et al. 2002; MacFadyen et al. 2004). Another study (Doyle et al. 2005) has shown that the effect of UVBR on phytoplankton growth is not only temperature dependent but also nutrient dependent. Therefore, studying the response of the entire plankton food web to multiple stressors linked to global change with an emphasis on direct (i.e., physiological) and indirect (i.e., positive or negative feedbacks) effects of complex interactions is essential to evaluating how global change will modify the structure and function of aquatic systems.

Water temperature and incident UVBR are expected to increase in coming decades as a result of concomitant global warming and ozone reduction (Weatherhead and Andersen 2006; IPCC 2007). Models predict an increase of $2.2-5.1^{\circ} \mathrm{C}$ in annual average temperature in the Mediterranean region by 2080-2099 (IPCC 2007). UVBR is expected to increase in European regions by about $10 \%$ in coming years, particularly during spring (Reuder et al. 2001). However, UVBR recovery to past levels is expected to occur between 2040 and 2070 (WMO 2007). In the context of these environmental changes, shallow coastal waters will be particularly affected by future temperature and UVBR increases. These ecosystems are particularly sensitive to these changes as a result of their relatively shallow depth and lengthy water residence time. In addition, modification of plankton community structure and functioning will have direct socio-economic implications because coastal waters are highly productive areas in terms of primary, secondary, and exploited-resources production (e.g., shellfish farming; Costanza et al. 1997).

The objective of the present study is to investigate the effects of single and combined temperature and UVBR increases on a coastal Mediterranean plankton food web. In particular, changes in the structure of the microbial components were studied during the spring productive season. A factorial mesocosm experiment that applied increases of $3{ }^{\circ} \mathrm{C}$ and $20 \%$ UVBR (relative to natural conditions) was carried out during spring 2006. These increases correspond to the mean temperature increase in the Mediterranean region expected by 2080-2099 (IPCC 2007) and the high-UVBR scenario for the European region during spring in future years (Reuder et al. 2001).

\section{Methods}

Experimental design-A mesocosm experiment was carried out from 29 March to 07 April 2006 at the Mediterranean platform for Marine Ecosystem Experimental Research (MEDIMEER). MEDIMEER is located in Sète in the South of France $\left(43^{\circ} 24^{\prime} 49^{\prime \prime} \mathrm{N}, 3^{\circ} 41^{\prime} 19^{\prime \prime} \mathrm{E}\right)$ on the shore of Thau Lagoon, a coastal Mediterranean lagoon. Mesocosms were $3 \mathrm{~m}$ high, $1.2 \mathrm{~m}$ wide, and were made of $200-\mu$ m-thick vinylacetate mixed-polyethylene film (Insinööritoimisto Haikonen Ky). The polyethylene film transmitted $53 \%$ and $77 \%$ of UVBR and photosynthetically available radiation $(400-700 \mathrm{~nm})$, respectively (Nouguier et al. 2007). Mesocosms were held at $1 \mathrm{~m}$ above the water surface by floating structures. Mesocosms were covered with the same polyethylene material during the night and during rain events to prevent contamination and water exchange.

Eight moored mesocosms were simultaneously filled on 29 March 2006 (hereafter called day 1) with pooled and screened $(<1000-\mu \mathrm{m})$ subsurface $(1-\mathrm{m})$ lagoon water. Mesocosms were filled with water pumped at the subsurface $(1 \mathrm{~m})$ near the MEDIMEER deck (maximum depth $3 \mathrm{~m}$ ). Each mesocosm had a maximum water column depth of $2 \mathrm{~m}$ and contained 2260 liters of lagoon water. At the end of the experiment, the remaining water volume was approximately 1800 liters. The water column in each mesocosm was constantly homogenized using a pump (Iwaki). The turnover time was set at $1 \mathrm{~h}$ and it was adjusted daily using a flowmeter according to the remaining water volume of each mesocosm after sampling. Previous tests showed that the pump did not affect abundances of bacteria, phytoplankton, heterotrophic flagellates, and ciliates, but the effect of pumping and the homogenization system on more fragile species is not excluded.

Four treatments were applied in duplicate mesocosms: (1) Control (C), (2) $20 \%$ increase in UVBR (UV) compared to natural incident UVBR received at the water surface in control mesocosms, (3) $3{ }^{\circ} \mathrm{C}$ increase in water temperature (T) compared to control mesocosms, and (4) combined increase in UVBR $(20 \%)$ and water temperature $\left(3^{\circ} \mathrm{C}\right)$ (UVT). Treatments began on 30 March (day 2) for enhanced temperature and on 31 March (day 3) for increased UVBR.

Increased temperature and UVBR treatments-Water temperature was increased using a submersible heating element (Galvatec) immersed vertically at a depth of $\sim 1 \mathrm{~m}$ (Nouguier et al. 2007). Incident UVBR at the water surface was increased using custom-built frames holding two UV fluorescent lamps (Philips TL20RS/01), a double electronic ballast (Bag electronics AD18.22310) controlled by voltage 
input, and an ultra-pure polished aluminum reflector. The lamp system was covered with a di-acetate cellulose sheet (which was changed daily) to avoid artificial ultraviolet $\mathrm{C}$ radiation. The lamp system was placed on the floating structure at $91 \mathrm{~cm}$ above the water surface.

An automatic system to regulate water temperature and UVBR enhancement was developed specifically for this experiment and has been described in Nouguier et al. (2007). We briefly describe the functioning of this automatic system here. The automatic system was based on closed-loop regulation. For temperature, regulation followed several steps: (1) monitoring of water temperature in all mesocosms every $30 \mathrm{~s}$ using thermistor probes (Campbell Scientific 107), (2) comparison of water temperatures in the control (reference temperature) and warmed mesocosms using a Campbell Scientific data logger (CR23X, Campbell Scientific), (3) monitoring of the deviation of water temperature in the warmed mesocosms from the target value (reference temperature plus $3.1^{\circ} \mathrm{C}$ ), and (4) starting the heating elements to reach the target value in the warmed mesocosms.

An automatic device was also designed to perform closed-loop regulation of increased UVBR. Incident UVBR was monitored every $30 \mathrm{~s}$ by a UVB radiometer (Skye ultraviolet sensor 430, Skye Instruments) installed on the roof of the control center to avoid shading. To better monitor UVBR increase, a master-slave system was implemented because of the impossibility of obtaining correct UVBR measurements under in situ conditions at the water surface. The master unit was installed in the control data center on a structure mimicking the upper part of the mesocosm. The slave units were placed above the experimental mesocosms. To monitor the UVBR delivered by the fluorescent lamps of the master unit, a UVB radiometer (Skye ultraviolet sensor 430, Skye Instruments) was installed at the base of the master structure. In addition, each fluorescent lamp on the master and slave mesocosms was individually monitored by a custom-built photodiode system (sglux TW30DZ) to control for any eventual lamp failure or discrepancy between the master and the slaves. Regulation of increased UVBR consisted of several steps: (1) rapid sampling $(2 \mathrm{~Hz})$ of incident and artificially enhanced UVBR, (2) real-time comparison of incident and enhanced UVBR, (3) establishment of the target value (incident UVBR multiplied by a coefficient), and (4) sending the proportional command to the UV lamps. The UVBR lamps and regulation system were turned on at $09: 45 \mathrm{~h}$ and switched off at 17:45 h local time (local zenith time was 13:45 h).

Physico-chemical sampling and measurements-Mesocosm temperature was monitored frequently (every $30 \mathrm{~s}$ ) at three depths $(0.4 \mathrm{~m}, 0.8 \mathrm{~m}$, and $1.2 \mathrm{~m})$ using thermistor probes (Campbell Scientific 107) from 30 March (day 2) to 07 April (day 10). Incident UVBR and enhanced UVBR were monitored by UVB radiometers from 31 March (day 3) to 07 April (day 10). UVBR (305 nm) was measured daily in the water column of mesocosms and in Thau Lagoon beside the mesocosms using a UV profiling radiometer (PUV-2500, Biospherical Instruments). The depths at which radiation corresponded to $1 \%$ of the UVB surface radiation were compiled for each treatment and for the lagoon throughout the experiment. The quantity of available data varied among treatments because the $1 \%$ depth occasionally exceeded the maximum depth reached by the profiling radiometer, depending on the shape of the mesocosm bags (C: $n=10$; UV: $n=17$; T: $n=$ 5; UVT: $n=11$; lagoon: $n=9$ ).

All mesocosms were sampled daily from 29 March (day 1) to 07 April (day 10) using 20-liter polycarbonate carboys cleaned with acid. Samples were taken at 09:00 h, before UVB lamps were switched on, except on 29 March (when samples were taken at 21:00 h, after filling the mesocosms). Aliquots were then sampled from the 20-liter polycarbonate carboys for chemical and biological analyses, except for metazooplankton and oxygen production analysis (see details below).

Nitrates $\left(\mathrm{NO}_{3}+\mathrm{NO}_{2}\right)$ and phosphates $\left(\mathrm{PO}_{4}\right)$ were measured in filtered (pre-combusted glass-fiber filters, $47-\mathrm{mm}$, Whatman GF/F) 80-mL aliquots using an automated colorimeter (Skalar), following standard nutrient analysis methods (Treguer and Le Corre 1975). Ammonium concentrations were measured in triplicate in unfiltered samples $(50 \mathrm{~mL})$ using a spectrophotometer (Hitachi U3000), following the indophenol blue method (Koroleff 1983).

Plankton biomass, abundance, and composition sampling and analysis-For metazooplankton analysis, samples (60 liters) were taken on days 2,6 , and 8 using three 20 liter polycarbonate containers and screened onto a $60-\mu \mathrm{m}$ sieve to collect and concentrate zooplankton in neutralized formalin (4\% final concentration). Metazooplankton was taxonomically enumerated using a Leica MZ6 dissecting microscope, following the technique of Rose (1933).

Heterotrophic flagellates (HF) and ciliates were sampled on days $2,4,6,8$, and 10. For HF enumeration, aliquots $(30 \mathrm{~mL})$ were preserved with formaldehyde (4\% final concentration). Next, $10-\mathrm{mL}$ subsamples were stained with 4',6'-diamidino-2-phenyindole hydrochloride and filtered onto $25-\mathrm{mm}$ black nucleopore polycarbonate membranes $(0.2-\mu \mathrm{m}$ pore size). Each filter was placed on a microscope slide, and HF were enumerated using an epifluorescence microscope (Olympus AX-70) with a $100 \times$ objective. For ciliate enumeration and identification, $125-\mathrm{mL}$ aliquots were preserved with acid Lugol's solution $(0.4 \%$ final concentration). Samples were then sedimented for $24 \mathrm{~h}$ in an Utermöhl's chamber and observed under an inverted microscope (Olympus IX-70).

Phytoplankton samples were collected daily $(500 \mathrm{~mL})$ for microscopic identification and preserved with formaldehyde (8\% final concentration) at $4{ }^{\circ} \mathrm{C}$ until analysis. Samples were then sedimented for $24 \mathrm{~h}$ in an Utermöhl's chamber and observed under an inverted microscope (Olympus IX-70).

Chlorophyll $a$ (Chl $a$ ) samples ( $0.5-1$ liter) were collected daily, filtered on glass-fiber filters $(25 \mathrm{~mm}, 0.7-\mu \mathrm{m}$ nominal pore size, Whatman $\mathrm{GF} / \mathrm{F})$ at low vacuum $(<200 \mathrm{~mm} \mathrm{Hg})$, and stored immediately in liquid nitrogen and then at $-80^{\circ} \mathrm{C}$ until analysis. Chl $a$ was extracted in $3 \mathrm{~mL}$ of $95 \%$ 
methanol for $1 \mathrm{~h}$ at $-20^{\circ} \mathrm{C}$, sonicated with a sonication probe for a few seconds, stored at $4^{\circ} \mathrm{C}$ for $1 \mathrm{~h}$, and then clarified on glass-fiber filters $(25 \mathrm{~mm}$, Whatman $\mathrm{GF} / \mathrm{F})$. Chl $a$ was analyzed by high-performance liquid chromatography (HPLC), following the method of Zapata et al. (2000), with some adaptations for the HPLC system used. The HPLC system was composed of a pump (600E, Waters) equipped with a $200-\mu \mathrm{L}$ loop, an automatic refrigerated $\left(4^{\circ} \mathrm{C}\right)$ injector (717plus autosampler, Waters), and a photodiode array detector (2996 PDA, Waters). Chl $a$ was identified based on retention time and the absorbance spectra obtained with the photodiode array. The HPLC was calibrated with commercial standards (DHI and Sigma).

Heterotrophic bacteria (hereafter called bacteria) samples $(1.6 \mathrm{~mL})$ were collected daily and preserved with formaldehyde ( $2 \%$ final concentration), then frozen in liquid nitrogen and stored at $-80^{\circ} \mathrm{C}$ until analysis. Bacterial samples were thawed at room temperature, and then nucleic acids were stained for $15 \mathrm{~min}$ in the dark at $4^{\circ} \mathrm{C}$ with SYBR Green I (1:10,000 vol: vol, Molecular Probes), according to the method described by Marie et al. (1997). Samples were analyzed using a FACSCalibur flow cytometer (Becton Dickinson) equipped with an air-cooled argon laser $(488 \mathrm{~nm}, 15 \mathrm{~mW})$. Bacteria were enumerated using their green fluorescence (FL1) collected at $530 \mathrm{~nm}$. Yellow-green fluorescent cytometry beads of $1-\mu \mathrm{m}$ and 2$\mu \mathrm{m}$ diameters (Polysciences) were added to the samples as internal standards for cell size and fluorescence emission, and TruCount control beads (Becton Dickinson) were added to determine the analyzed volumes.

For virus enumeration, subsamples were taken daily, fixed with $0.02-\mu \mathrm{m}$ of filtered buffered formaldehyde ( $2 \%$ final concentration), and stored at $-80^{\circ} \mathrm{C}$ until further analysis. After thawing, viruses were stained with SYBR Gold nucleic acid stain (Molecular Probes), as described by Chen et al. (2001), and filtrated (15-kPa vacuum) through $0.02-\mu \mathrm{m}$ pore-size Anodisc membrane filters (Whatman). Virus-like particles were counted under blue light $(488 \mathrm{~nm})$ using an Olympus AX-70 epifluorescence microscope.

Oxygen production and dark community respiration rates - Net microbial oxygen production and dark community respiration rates were measured every $2 \mathrm{~d}$ (on days $2,4,6,8$, and 10) in all mesocosms by following changes in dissolved oxygen concentrations in quartz and in borosilicate darkened bottles, respectively, both of which were incubated during the light period (from ca. 09:00 h to ca. 18:00 h) in the mesocosms (ca. 0.50-m depth). Mesocosm water for these incubations was sampled using 9-liter carboys cleaned with acid and was kept in darkness. Six 120 -mL borosilicate bottles and two $120-\mathrm{mL}$ quartz bottles were carefully filled from each carboy using a silicone tube. Three borosilicate bottles were immediately fixed (time zero) using reagents prepared following the recommendations of Carritt and Carpenter (1966).

The two quartz bottles and three other darkened borosilicate bottles were incubated in their respective mesocosms for about $9 \mathrm{~h}$ and were then fixed as described above. Dissolved oxygen concentrations were determined using an automated Winkler titrator based on potentiometric detection (Crisson). Net oxygen production rate was calculated as the difference between the dissolved oxygen concentrations measured at time zero and at the end of the incubation period in the quartz bottles. Dark community oxygen respiration rate was calculated as the difference between the dissolved oxygen concentrations measured at time zero and at the end of the incubation period in the darkened bottles. Rates were expressed in $\mathrm{mg} \mathrm{O}_{2} \mathrm{~L}^{-1} \mathrm{~h}^{-1}$. Gross oxygen production rates were calculated as the sum of net oxygen production and dark oxygen respiration rates.

Microbial plankton carbon biomass estimates-Microbial carbon biomass was estimated using the following carbon conversion factors: $20 \mathrm{fg} \mathrm{C}^{\mathrm{C}}$ cell ${ }^{-1}$ for bacteria (SimeNgando et al. 1995), $0.22 \mathrm{pg} \mathrm{C} \mu \mathrm{m}^{-3}$ for HF (Booth 1993), and $0.21 \mathrm{pg} \mathrm{C} \mu \mathrm{m}^{-3}$ for ciliates (Putt and Stoecker 1989); a $\mathrm{C}: \mathrm{Chl} a$ ratio of 57 was used to estimate the carbon biomass of phytoplankton (Latasa et al. 2005). Total microbial carbon biomass was then computed as the sum of the estimated carbon biomass of bacteria, phytoplankton, heterotrophic flagellates, and ciliates.

Statistical analysis - Repeated-measures analyses of variance (RM-ANOVAs) were used to test the effects of UVBR, temperature, and simultaneous increases in UVBR and temperature on plankton abundance and biomass, with days as a repeated factor (SYSTAT version 11). Because the number of subjects (mesocosms) was less than the number of factors (days), univariate tests were computed. All analyses were performed on $\log _{10}$-transformed data to normalize variance, and sphericity was verified before performing RM-ANOVA; $p$-values less than or equal to 0.05 were considered to indicate statistically significant differences.

\section{Results}

Physico-chemical conditions-Average daily temperature naturally increased from day 2 to day 6 from $13.2^{\circ} \mathrm{C}$ to $15.4^{\circ} \mathrm{C}$ in control and UV mesocosms (Fig. 1a), followed by a decrease to $14.6^{\circ} \mathrm{C}$ and then stabilization at $15.1^{\circ} \mathrm{C}$. Warmed mesocosms ( $\mathrm{T}$ and UVT) followed the same trend as controls, with a constant daily difference of $3.1^{\circ} \mathrm{C}$ (Fig. 1a), except on day 2, when heating began.

Natural daily UVBR doses received at the water surface of the mesocosms varied from 20 to $47 \mathrm{~kJ} \mathrm{~m}^{-2}$ (Fig. 1b), with half the UVBR dose received on cloudy days (day 3 ). The increased-UVB mesocosms (UV and UVT) received precisely $20 \%$ more than the natural daily UVBR, and the maximum daily UVBR dose (natural+added UVBR) never exceeded $57 \mathrm{~kJ} \mathrm{~m}^{-2}$ (Fig. 1b). Less-penetrant UVB radiation $(305 \mathrm{~nm})$ reached the lower half of the mesocosm water column on most days of the experiment, as shown in Fig. 2. The $1 \%$ depth of UVBR did not differ significantly between treatments and was comparable to the $1 \%$ depth measured in the adjacent lagoon water column (Fig. 2).

Dissolved inorganic nitrogen (DIN, $\mathrm{NO}_{3}+\mathrm{NO}_{2}+\mathrm{NH}_{4}$ ) concentrations ranged from 0.1 to $1.6 \mu \mathrm{mol} \mathrm{L}^{-1}$ (treatment 

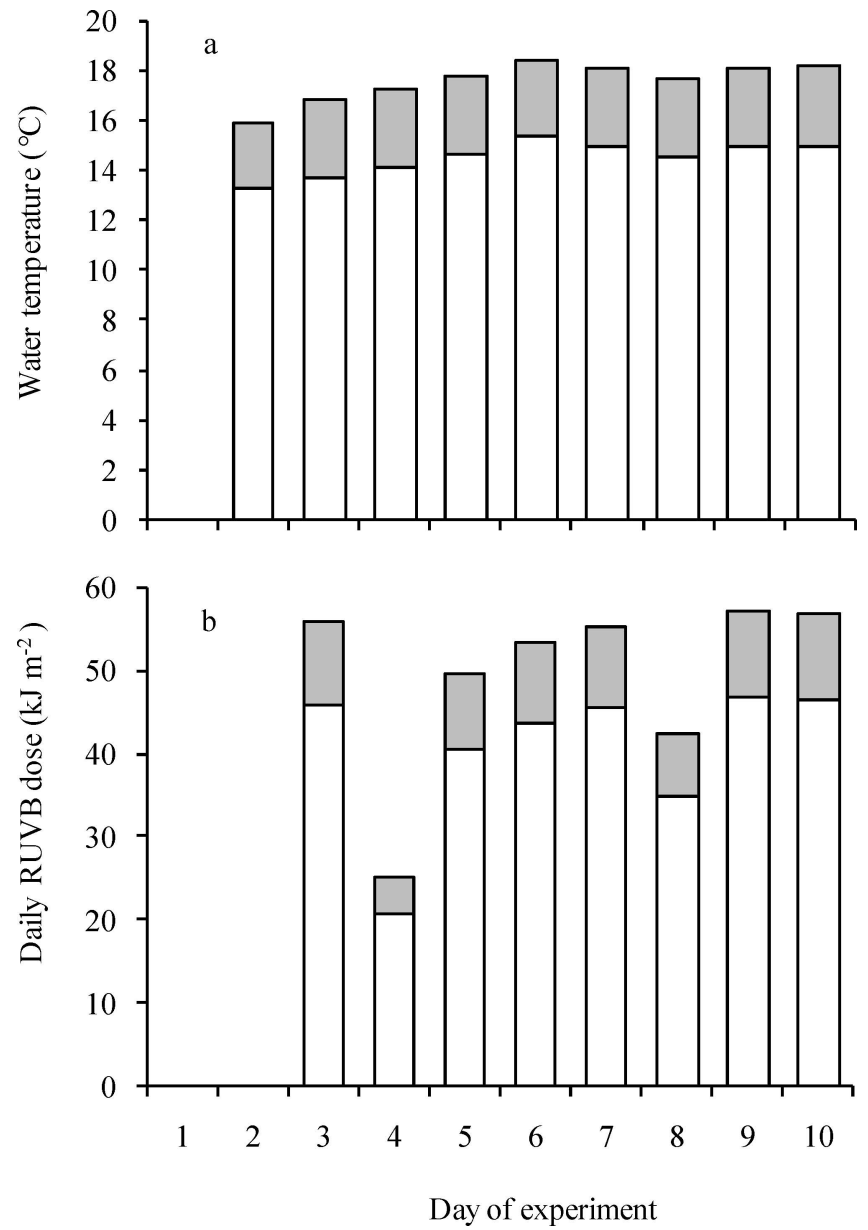

Fig. 1. (a) The daily average water temperature in nonheated mesocosms (white bar, control and increased UVB) and the increased temperature in heated mesocosms (gray bars, increased temperature and simultaneous UVB and temperature increase mesocosms) during the experiment. Symbols represent averages of the daily values (averages of measurements made every $20 \mathrm{~s}$ at three different depths) of the two mesocosms receiving the same treatment. (b) The average daily UVBR dose received at the water surface: white bars indicate the natural UVBR dose received by all mesocosms, and gray bars indicate the artificial UVBR dose added in increased UVB and simultaneous UVB and temperature increase treatments.

average; Fig. 3a). DIN concentrations increased slightly on the first day of the experiment and then generally decreased in all treatments throughout the experiment (Fig. 3a). Dissolved inorganic phosphorous (DIP, $\mathrm{PO}_{4}$ ) concentrations ranged from undetectable levels to $0.09 \mu \mathrm{mol} \mathrm{L}^{-1}$ (treatment average; Fig. 3b). DIP concentrations decreased to undetectable levels on day 2 or day 3 (according to the treatment), but then tended to increase until day 8 for all treatments, except in UV mesocosms, where DIP tended to increase until day 6 (Fig. 3b). Later, DIP concentrations slightly decreased in all treatments at the end of the experiment. DIN and DIP concentrations did not differ significantly between control mesocosms and treatments.

Meta- and protozooplankton-The metazooplankton community was dominated by copepods, cirripeds, troco-

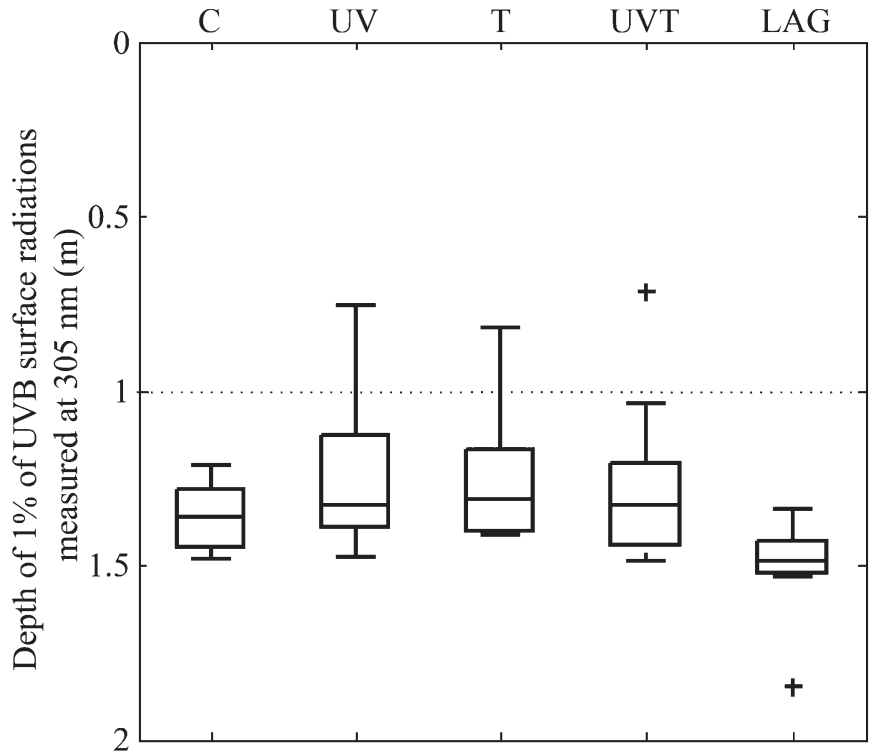

Fig. 2. Variability of the depth of $1 \%$ UVB penetration $(305 \mathrm{~nm})$ for each treatment and in the lagoon (LAG) throughout the experiment. Horizontal lines in each box display the lower quartile, median, and upper quartile values. Whiskers show the range of the rest of the data. The maximum whisker length corresponds to 1.5 units of the interquartile range. Crosses represent outliers. The horizontal dotted line at $1 \mathrm{~m}$ shows the middle depth of the water column in the mesocosm bags.

phore and oyster larvae, a few gastropod mollusks (Limacina sp.), and decapods. Small (ca. 1.2-mm) calanoid copepods (mainly Temora sp. and Centropages sp.) dominated the metazooplankton community in all mesocosms throughout the experiment. At the beginning of the experiment, only copepodite and nauplii stages were observed. The most interesting result was the significant positive effect of warming on copepod development time, as shown by the earlier observation of adult stages, particularly females, in warmed treatments than in control and increased-UV treatments (on day 6 in T and UVT; Fig. 4; Table 1). This faster development of calanoid copepods was also observed at the nauplii level, as nauplii abundance decreased (through progression into copepodite stages) faster under warmer treatments ( $T$ and UVT; Fig. 4c; Table 1). From day 8, copepod adult stages were also observed in $\mathrm{C}$ and $\mathrm{UV}$ treatments, but in lesser abundance than those observed in T and UVT. Earlier formed females will also have earlier spawning capacities, as observed in the increased number of nauplii between days 6 and 8 in the T and UVT treatments.

The HF community was dominated by small cells (3$5 \mu \mathrm{m}$ in diameter). HF abundance responded positively to warming. HF abundances observed on day 6 under T and UVT treatments were $217 \%$ and $113 \%$ higher, respectively, than those observed in controls (Fig. 5a). This increase under warming was confirmed by inverted-microscope observations of abundant small $(3-5-\mu \mathrm{m})$ choanoflagellates on day 6.

Ciliates were dominated by small ciliates $(10-25 \mu \mathrm{m})$. The ciliate community was dominated by oligotrich ciliates 


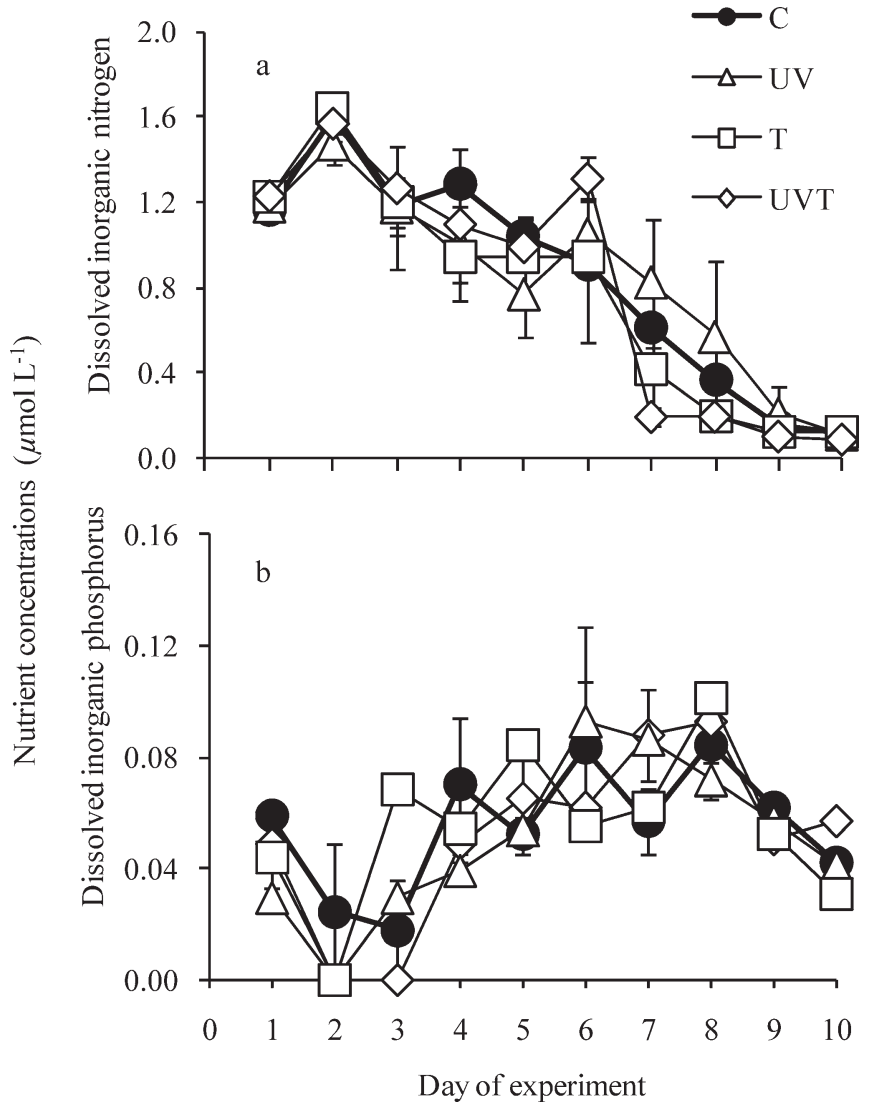

Fig. 3. (a) DIN and (b) DIP under different treatments: Control (C); $20 \%$ increase in ultraviolet $\mathrm{B}$ incidence (UV); $3^{\circ} \mathrm{C}$ increase in temperature $(\mathrm{T})$; simultaneous increases in temperature $\left(3^{\circ} \mathrm{C}\right)$ and ultraviolet B incidence $(20 \%)$ (UVT). Symbols represent means for each treatment (averages of the two mesocosms receiving the same treatment), and error bars indicate the ranges of the observations. Note that DIN on day 1 is the sum of $\mathrm{NO}_{3}$ and $\mathrm{NO}_{2}$ only $\left(\mathrm{NH}_{4}\right.$ was not measured on this day).

(Strombilidium, Strombidium, and Strombidinopsis). Warming significantly affected ciliate abundance (Table 1), but in opposite directions for short-term and long-term effects (Fig. 5b). On day 4, ciliate abundance was greater under warming (by $166 \%$ and $86 \%$ for T and UVT, respectively), relative to controls. However, on days 8 and 10, ciliate abundance under warming (T and UVT) was as low as $86 \%$ of the abundance measured in controls (Fig. 5b).

Phytoplankton, bacteria, and viruses-The phytoplankton community was initially composed of cryptophytes, naked dinoflagellates, diatoms, and prasinophytes in all mesocosms. This community shifted to a community dominated by diatoms and prymnesiophytes at the end of the experiment (results not shown). A phytoplankton bloom occurred at days 7 and 9 for warmer and control mesocosms, respectively, as shown by maximum $\mathrm{Chl} a$ concentrations (Fig. 6a). Microscopic observations indicated that the phytoplankton bloom observed was mainly dominated by the chain-forming diatom Cerataulina pelagica (Cleve) Hendey 1937 (data not shown).
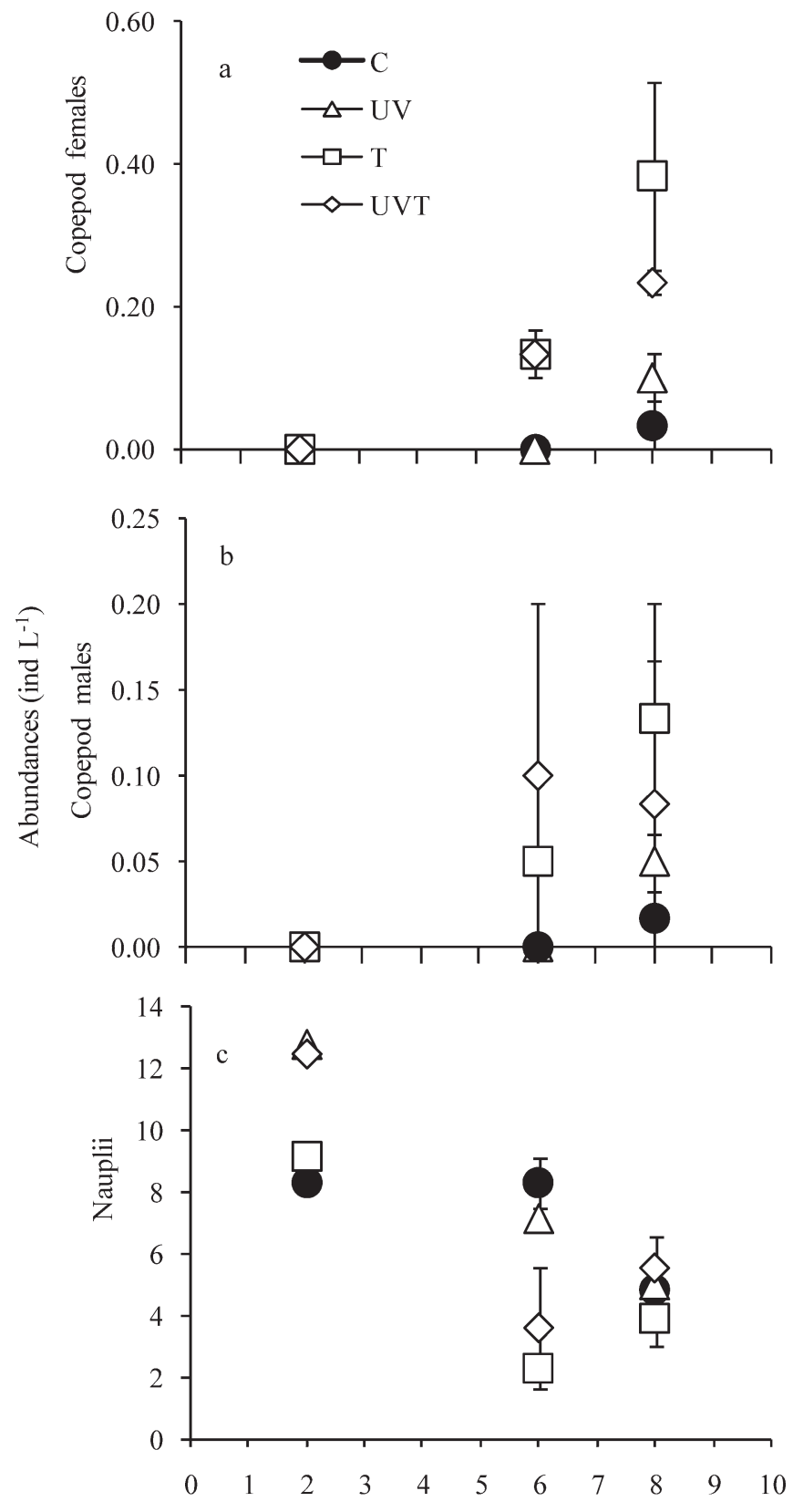

Day of experiment

Fig. 4. Abundances of (a) female copepods, (b) male copepods, and (c) nauplii under different treatments: Control (C); $20 \%$ increase in ultraviolet B incidence (UV); $3^{\circ} \mathrm{C}$ increase in temperature $(\mathrm{T})$; simultaneous increases in temperature $\left(3^{\circ} \mathrm{C}\right)$ and ultraviolet B incidence (20\%) (UVT). Symbols represent means for each treatment (averages of the two mesocosms receiving the same treatment), and error bars indicate the ranges of the observations.

There was no significant treatment effect on bulk phytoplankton as measured by Chl $a$ (Table 1). However, warming ( $\mathrm{T}$ and UVT) induced an earlier increase in biomass; maximum $\mathrm{Chl} a$ biomass was observed $2 \mathrm{~d}$ earlier in warmer mesocosms than in control mesocosms (days 7 and 9 for warmer and control mesocosms, respectively; 
Table 1. RM-ANOVA results for the effects of increased ultraviolet B radiation (UV), increased temperature (T), and simultaneously increased ultraviolet B radiation and temperature (UVT) and time on viruses, heterotrophic bacteria, heterotrophic flagellates (HF), ciliates, nauplii, female copepods, male copepods, and Chl $a$. Data given are $F$-values.

\begin{tabular}{|c|c|c|c|c|c|c|c|c|}
\hline Source & Viruses & Bacteria & $\mathrm{HF}$ & Ciliates & Nauplii & $\begin{array}{l}\text { Female } \\
\text { copepods }\end{array}$ & $\begin{array}{c}\text { Male } \\
\text { copepods }\end{array}$ & Chl $a$ \\
\hline$\overline{\mathrm{UV}}$ & 0.58 & 5.51 & 0.50 & 12.71 & 0.14 & - & - & 0.58 \\
\hline $\mathrm{T}$ & 0.97 & $31.64 *$ & 0.00 & $85.53 * *$ & $21.11^{*}$ & $29.23^{*}$ & 12.38 & 0.10 \\
\hline UVT & 1.69 & $62.31 *$ & 0.15 & $628.53^{* *}$ & 1.43 & $19.72 *$ & 14.30 & 0.17 \\
\hline Time $\times$ UV & $3.70 *$ & 0.40 & 0.75 & 1.21 & 0.01 & - & - & 0.26 \\
\hline Time $\times \mathrm{T}$ & 0.87 & 0.36 & 1.66 & $6.03 *$ & 4.74 & 0.02 & 0.15 & 1.30 \\
\hline Time $\times$ UVT & 0.97 & 0.71 & 0.02 & $6.11 *$ & 2.47 & 0.18 & 0.06 & 0.79 \\
\hline
\end{tabular}

$* p \leq 0.05 ; * * p \leq 0.01$.

Fig. 6a). Nevertheless, maximum Chl a concentrations were similar in all treatments (around $1.8 \mathrm{mg} \mathrm{L}^{-1}$ ).

Temporal patterns of bacterial abundance were similar under all treatments, with an initial rapid increase from day 1 to day 3 followed by a decline in abundance until day 7 or day 8 , depending on the treatment. Subsequently, constant levels were observed until the end of the experiment (Fig. 6b). Warmer treatments displayed significantly reduced bacterial abundance from day 5 to day 7 (by $38 \%$
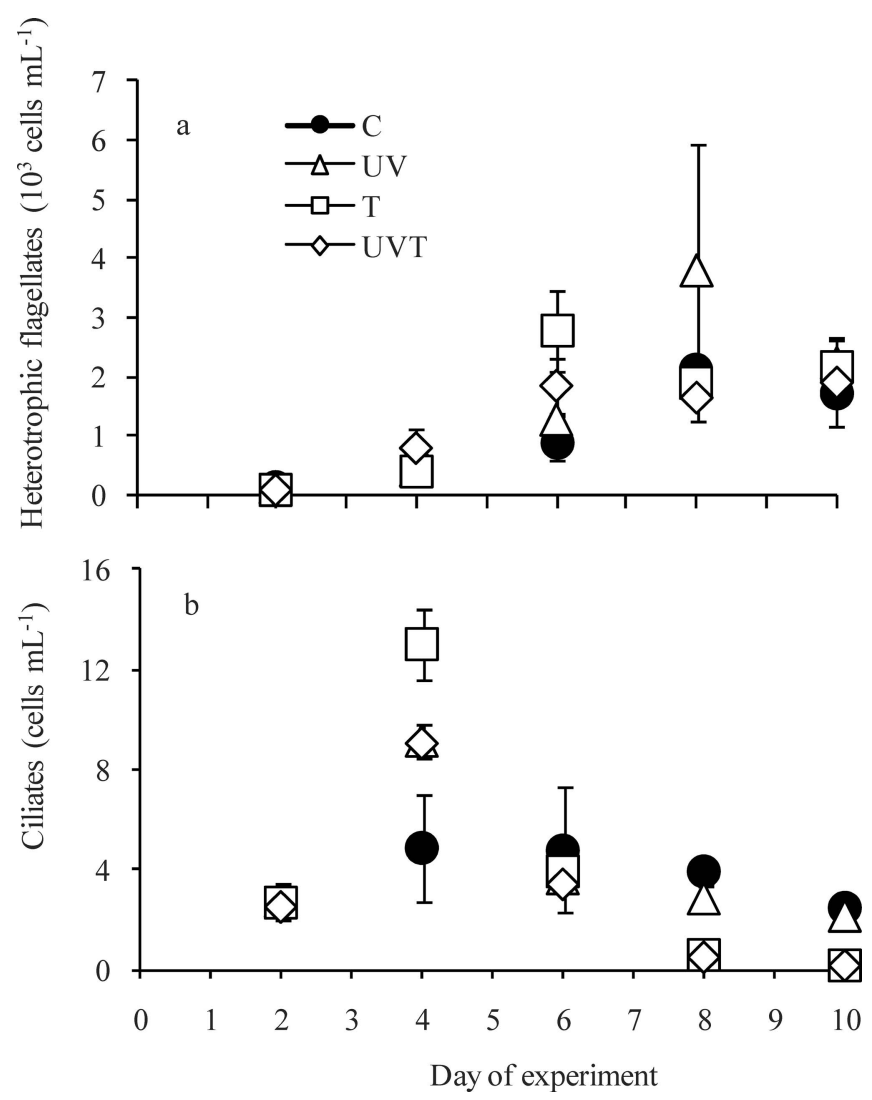

Fig. 5. Abundances of (a) HF and (b) ciliates under different treatments: Control (C); $20 \%$ increase in ultraviolet B incidence (UV); $3{ }^{\circ} \mathrm{C}$ increase in temperature (T); simultaneous increases in temperature $\left(3^{\circ} \mathrm{C}\right)$ and ultraviolet $\mathrm{B}$ incidence (20\%) (UVT). Symbols represent means for each treatment (averages of the two mesocosms receiving the same treatment), and error bars indicate the ranges of the observations.
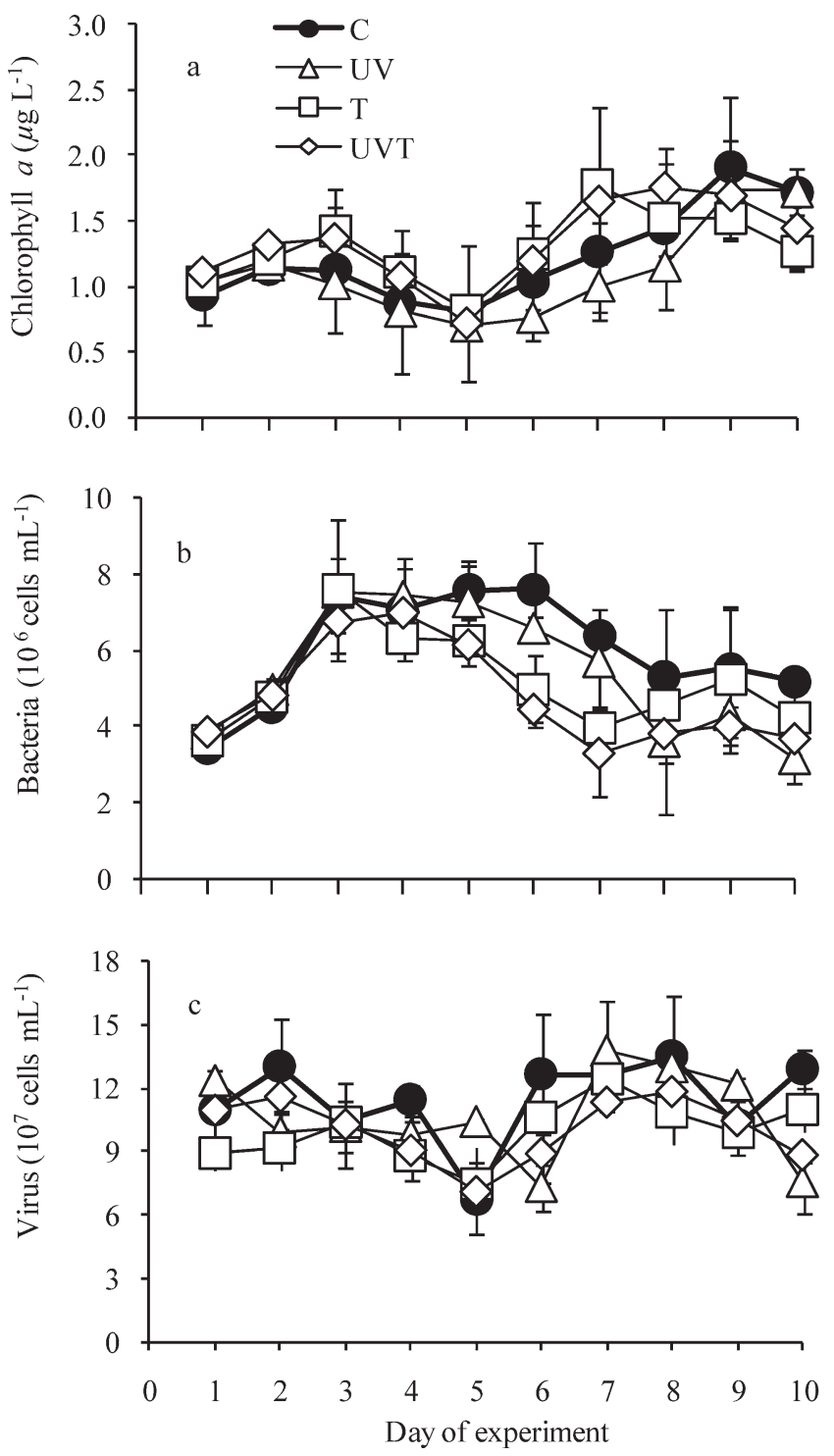

Fig. 6. (a) Chl $a$ concentrations and abundances of (b) bacteria and (c) viruses under different treatments: Control (C); $20 \%$ increase in ultraviolet $\mathrm{B}$ incidence (UV); $3^{\circ} \mathrm{C}$ increase in temperature $(\mathrm{T})$; simultaneous increases in temperature $\left(3^{\circ} \mathrm{C}\right)$ and ultraviolet B incidence (20\%) (UVT). Symbols represent means for each treatment (averages of the two mesocosms receiving the same treatment), and error bars indicate the ranges of the observations. 


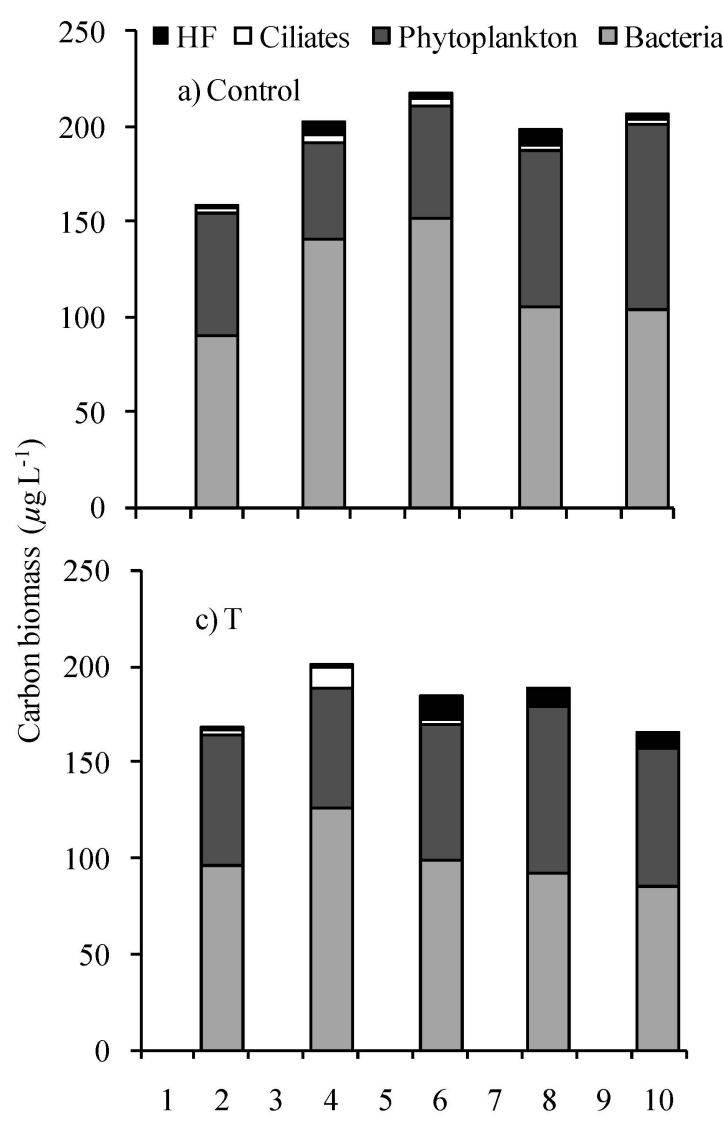

Day of experiment
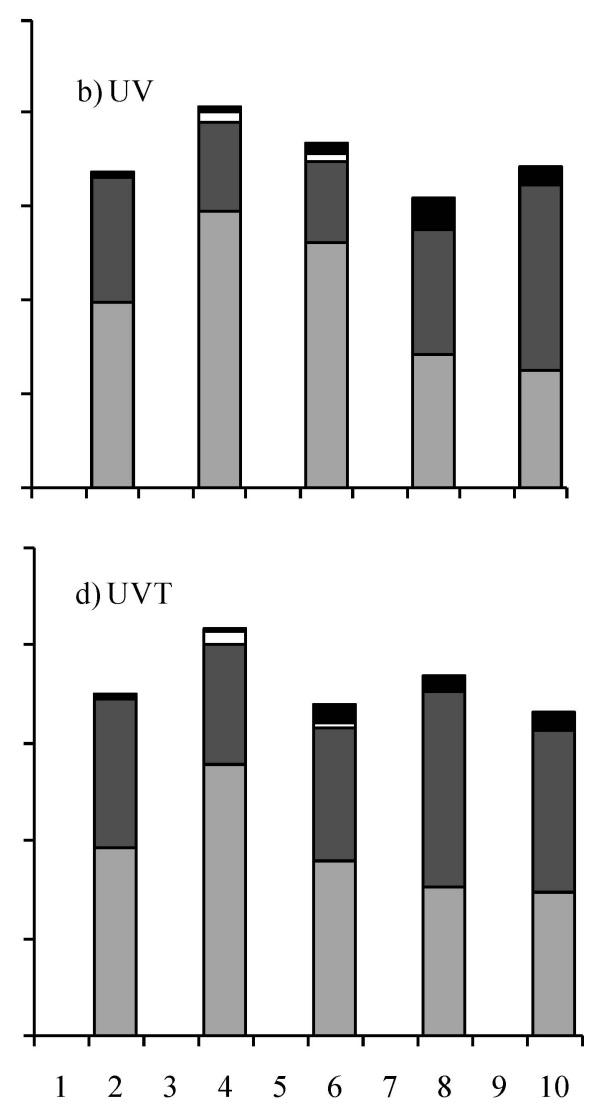

Day of experiment

Fig. 7. HF, ciliate, phytoplankton, and bacterial carbon biomasses under (a) control, (b) increased ultraviolet B radiation (UV), (c) increased temperature (T), and (d) simultaneous increased temperature and ultraviolet $\mathrm{B}$ radiation (UVT).

and $48 \%$ for $\mathrm{T}$ and UVT, respectively) (Fig. 6b; Table 1), compared to controls. The general pattern of virus abundance showed a decrease from the beginning of the experiment until day 5 (day 6 for UV), followed by an increase, with maximum values reached on day 7 or day 8 , depending on the treatment. Warming and increased UVBR had no significant effects on virus abundance (Fig. 6c). However, UVBR delayed by $1 \mathrm{~d}$ the decline in virus abundance, which was observed on day 6 in UV and on day 5 under other treatments.

Microbial carbon standing stocks - Estimated microbial carbon biomass was dominated by bacteria, with averaged mesocosm biomass ranging from 71 to $152 \mu \mathrm{g} \mathrm{C} \mathrm{L} \mathrm{L}^{-1}$ (Fig. 7), representing an average of $56 \% \pm 11 \%$ (all mesocosms throughout the experiment) of the total microbial carbon biomass. Average phytoplankton carbon concentrations ranged from 43 to $100 \mu \mathrm{g} \mathrm{C} \mathrm{L}^{-1}$ (Fig. 7), representing an average of $35 \% \pm 9 \%$ of the total microbial carbon biomass. Protozooplankton (HF and ciliates) carbon concentrations were generally low (Fig. 7), contributing averages of $3 \% \pm 3 \%$ and $1 \% \pm 1 \%$ of total microbial carbon biomass, respectively. Warming ( $\mathrm{T}$ and UVT) induced a decrease in bacterial carbon biomass and an increase in phytoplankton, especially on days 6 and 8
(Fig. 7). UVBR alone generally had minor effects on microbial carbon biomass.

Oxygen production and respiration-Community net oxygen production ranged from -0.005 to $0.041 \mathrm{mg} \mathrm{O}_{2}$ $\mathrm{L}^{-1} \mathrm{~h}^{-1}$, but most measured values were positive (i.e., mostly oxygen production instead of respiration; Fig. 8a). Community gross oxygen production and dark respiration ranged from 0.001 to $0.048 \mathrm{mg} \mathrm{O}_{2} \mathrm{~L}^{-1} \mathrm{~h}^{-1}$ and from 0.002 to $0.010 \mathrm{mg} \mathrm{O}_{2} \mathrm{~L}^{-1} \mathrm{~h}^{-1}$, respectively (Fig. 8b,c). Net oxygen production generally increased throughout the experiment in all mesocosms, except on day 2 in the UVT treatment and on day 4 in the control and UV treatments, when negative values (i.e., mostly oxygen respiration) were measured (Fig. 8a). Increased temperature, alone or combined with increased UVBR, increased net oxygen production by $10 \%$ to $106 \%$, respectively, relative to values measured in controls (Fig. 8a). In contrast, increased UVBR alone had no effect, and community net oxygen production levels were similar to those measured in controls (Fig. 8a). Community gross oxygen production followed the same pattern as the net oxygen production (Fig. 8b), with values measured on day 6 , under increased temperature alone or combined with increased UVBR, measuring 12 and 15 times higher than those measured in controls (Fig. 8b). In contrast, the 

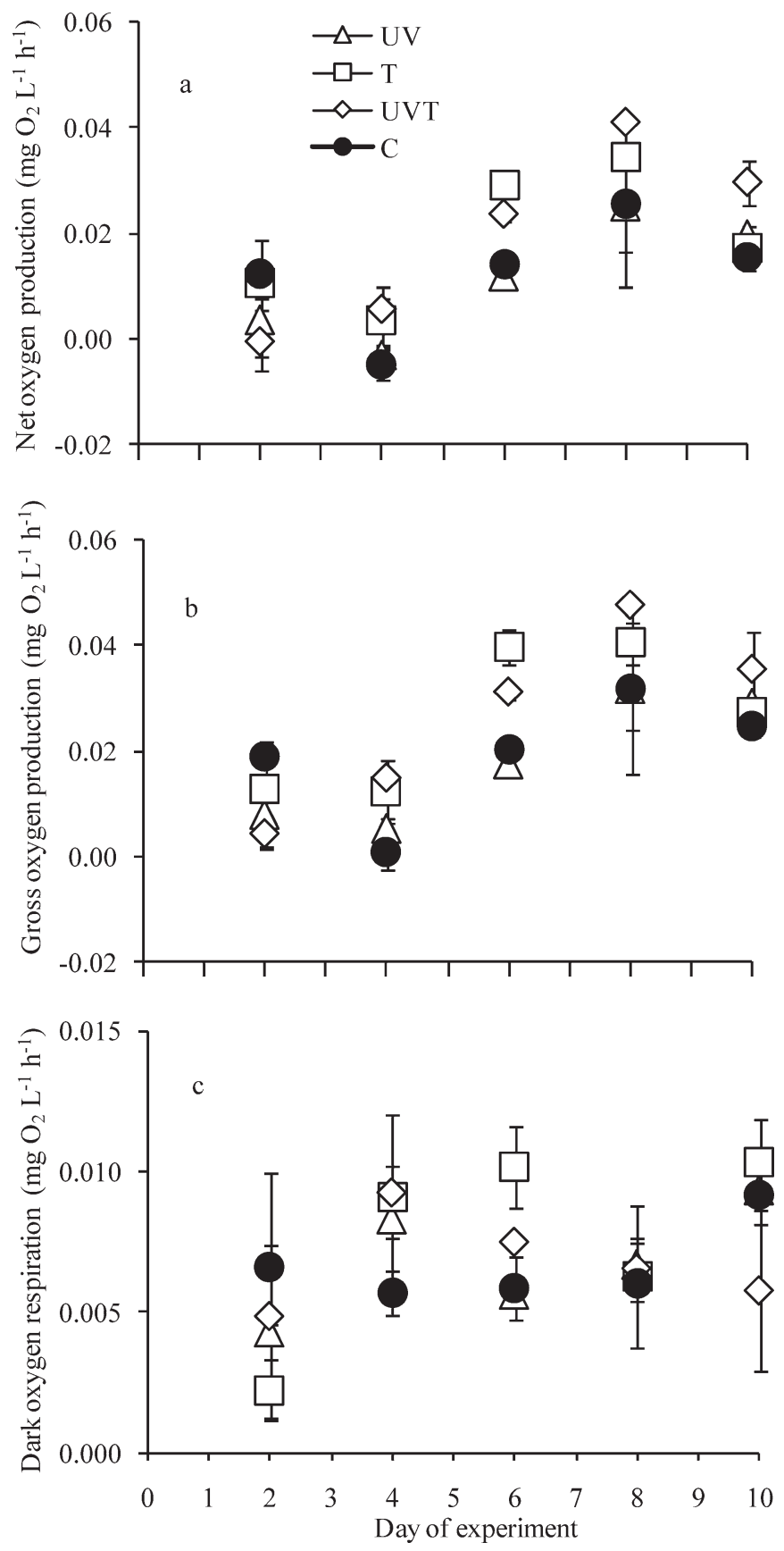

Fig. 8. (a) Net and (b) gross oxygen production and (c) dark oxygen respiration under different treatments: Control (C); 20\% increase in ultraviolet $\mathrm{B}$ incidence (UV); $3{ }^{\circ} \mathrm{C}$ increase in temperature $(\mathrm{T})$; simultaneous increases in temperature $\left(3^{\circ} \mathrm{C}\right)$ and ultraviolet B incidence (20\%) (UVT). Symbols represent means for each treatment (averages of the two mesocosms receiving the same treatment), and error bars indicate the ranges of the observations.

different treatments (T, UVT, and UV) had no significant effects on the community dark respiration rates even if a slight increase was observed at the beginning of the experiment under increase of temperature alone and combined with increased UVBR (days 4 and 6; Fig. 8c).

\section{Discussion}

It is widely recognized that temperature has a major influence on the physiology of organisms because it controls basic metabolic processes. In particular, maximal growth rates of both autotrophic and heterotrophic organisms increase with temperature (Eppley 1972; Rose and Caron 2007). A major result of our study was the significant response of heterotrophic predators to warming, inducing increases in copepod, ciliate, and HF abundances (until day 4 for ciliates and until day 6 for HF and copepods). Indeed, copepods developed more rapidly under warmer conditions. At the beginning of the experiment, only copepodites were observed, and these copepodites developed into adults $2 \mathrm{~d}$ faster (day 6) under warming conditions than in other treatments (day 8). This result is consistent with those of several studies that have reported temperature-dependent development of zooplankton, particularly reduced copepod development time from eggs to adults with increasing temperatures (Hart and McLaren 1978). Spawning will also occur sooner when water temperatures are increased.

Heterotrophic protists have been demonstrated to have high potential growth rates and a rapid response to increasing temperature (Caron et al. 1991), like the ciliates in this experiment. Ciliate abundance increased only a few days after applying the warming treatment. Larger standing stocks of ciliates with increased temperature were correlated to relatively greater abundance of their potential prey (i.e., small flagellates) and scarcity of their potential predators (i.e., adult copepods) at the beginning of the experiment. Weak top-down control of ciliates at the beginning of the experiment is supported by the fact that the standing stock of ciliates declined from day 6 onward under warming, as soon as their potential predators (adult copepods) appeared on day 6 in warmed mesocosms. The decline in ciliates after day 6 under warming explains the concomitant increase of their potential prey (HF). Therefore, our results illustrate a trophic cascade effect (copepods-ciliates-HF) under warming. Heterotrophic protists tightly control the abundance of their prey because they have rapid growth rates similar to those of their prey at intermediate and high temperatures (above $15^{\circ} \mathrm{C}$ for herbivorous protists; Rose and Caron 2007). The results of the present study also support the capacity of metazoan copepods to develop faster in warmer waters (at temperatures between $16^{\circ} \mathrm{C}$ and $18^{\circ} \mathrm{C}$ ). Consequently, copepods can also tightly control the abundance of their prey. Therefore, we did not observe a mismatch between increases in microplankton and zooplankton development, as suggested for Baltic plankton food webs under global warming (Edwards and Richardson 2004). In contrast, we observed rapid growth of copepods, illustrating a typical increase in predator abundance following an increase in abundance of its prey. This indicates an efficient transfer of carbon between microplankton and metazooplankton.

An unexpected result of this experiment was the reduced abundance of heterotrophic bacteria under warming. Viruses did not seem to be affected by temperature, at least in terms of abundance; thus, viral infection is 
apparently not the cause of bacterial decrease. Therefore, the decrease in bacterial abundance was probably due to stronger grazing control under warming. This observation is consistent with that reported by Weitere et al. (2008) for natural river plankton; they showed a decrease in bacterial abundance under warming, indicating a food web cascade effect. It has been shown that bacterivorous protists have greater maximal growth rates than herbivorous protists. Thus, they can control their prey more efficiently (Rose and Caron 2007). In addition, bacterivorous grazing rates can be enhanced with increasing temperature (reviewed in Rose and Caron [2007]). Thus, even if temperature can potentially enhance bacterial growth rates, increasing their abundance in the absence of bacterivorous protists, bacterial standing stocks may be strongly controlled by bacterivorous protists such as HF. Substrate availability (quality and quantity), which interactively limits bacterial growth with temperature (Pomeroy and Wiebe 2001), is apparently not the cause of the bacterial decrease under warming. Bacterial abundances increased considerably at the beginning of the experiment in all mesocosms, including warmed mesocosms. Conjointly dissolved organic carbon was relatively abundant (F. Vidussi unpubl.). Thus, bacteria were probably not substrate limited, at least at the beginning and at the midway of the experiment.

The increase in microbial predators (principally ciliates) and the positive response of adult copepods (as indicated by their faster appearance) under warming explain the small effect of warming on standing stocks of phytoplankton (i.e., Chl a). Two hypotheses can be proposed to explain how zooplankton controlled standing stocks of phytoplankton under warming. The first hypothesis is that herbivorous microzooplankton had growth rates similar to those of phytoplankton at temperatures encountered during the experiment $\left(13-15^{\circ} \mathrm{C}\right.$ in unheated mesocosms and $16-18^{\circ} \mathrm{C}$ in warmed mesocosms; Fig. 1a) and controlled phytoplankton standing stocks until the midway point of the experiment. Then at the midway point of the experiment, adult copepods appeared and therefore controlled phytoplankton standing stocks. The second hypothesis is that increased temperature enhanced herbivorous grazing rates. Recently, Rose and Caron (2007) have reviewed the effect of temperature on microzooplankton growth rates and have reported relationships between temperature and maximal growth rates of herbivorous protists, copepods, and their phytoplankton prey. They have shown that maximal growth rates of herbivorous protists exceed maximal growth rates of phototrophic protists (phytoplankton) at temperatures above $15^{\circ} \mathrm{C}$, indicating that the mismatch between the growth rates of phytoplankton predators and their prey at temperatures below $15^{\circ} \mathrm{C}$ can explain phytoplankton blooms. During our study, temperatures in unheated mesocosms were always less than $15^{\circ} \mathrm{C}$, except on day 6 . In contrast, temperatures in heated mesocosms were always greater than $15^{\circ} \mathrm{C}$. Thus, herbivorous protists could have higher growth rates than phytoplankton and thereby control standing stocks of phytoplankton, particularly small phytoplankton, until the midway point of the experiment. Our second hypothesis is that warming enhanced herbivorous grazing rates (re- viewed in Rose and Caron [2007]; Larsen and Riisgard [2009]). Even if phytoplankton growth was greater under warming, temperature-enhanced grazing rates may have prevented phytoplankton biomass accumulation. Phytoplankton did not appear to be especially more nutrient limited under warmer conditions; it increased in all mesocosms, and no significant differences in nutrient concentrations were observed between warmer and control mesocosms. However, nutrient limitation may have occurred, particularly at the end of the experiment, which could have provoked stronger nutrient competition between different phytoplankton groups and between phytoand bacterioplankton.

Overall, increased UVBR had moderate effects on the structure of the plankton food web. Indeed, only slight decreases in phytoplankton biomass (Chl $a$; Fig. 6a) and bacterial abundance were observed under increased UVBR (Fig. 6b). The negative effect of increased UVBR on bacteria and phytoplankton, although not statistically significant, might be due to a direct effect and not to an interaction-mediated effect because clear effect of UVBR on predators was not observed. These results are consistent with previous observations, which have indicated that UVBR effects on aquatic ecosystems are subtle rather than drastic (Vincent and Roy 1993). The moderate effects of increased UVBR on the entire plankton food web observed in this study might be explained by the moderate natural daily UVBR dose combined with a relatively UVBRresistant plankton community in early spring in the northern Mediterranean. Even if increased UVBR during our study exceeded natural doses, it was probably insufficient to induce effective damage in plankton, and repair mechanisms might remain efficient under these conditions. Furthermore, even though potentially damaging UVBR reached most of the mesocosm water column, the water-column mixing applied during the experiment may have contributed to the moderate UVBR effect. Natural mixing is known to facilitate repair processes and reduce the exposure of plankton to UVBR (Neale et al. 1998).

The moderate responses of the Mediterranean microbial food web and copepod communities to increased UVBR observed during this study contrast with the findings of previous studies carried out in coastal waters (Mostajir et al. [1999], in the St. Lawrence Estuary) that have shown significant effects of increased UVBR on large phytoplankton and ciliates. Comparison of the present study with previous studies that have reported significant harmful effects of UVBR on planktonic food webs allows us to underline two major concerns. The first concern is the enhanced UVBR dose applied during the experiment. We emphasize the need to apply realistic UVBR doses that mimic future increases in UVBR, taking into account the natural variability of UVBR. The second consideration is that the responses of plankton food webs to increased UVBR depend on local conditions. The effects of UVBR depend not only on the life histories of the organisms (acclimation) but also on the adaptations of local organisms to specific stresses. Therefore, local conditions (e.g., light and temperature levels, resource supply) must be carefully taken into consideration to better predict the effects of 
global changes on the functioning and structure of plankton food webs. The results presented here demonstrate that the expected future increase in UVBR has no statistically significant effects at the community level or on the structure of the marine food web during a spring bloom in the Mediterranean Sea. However, our results do not exclude the possibility that natural UVBR levels in the Mediterranean Sea are damaging to sensitive species, as previously reported for summer communities (Sommaruga et al. 2005).

The simultaneous increase in temperature and UVBR generally had no synergistic effects on the plankton food web structure during this study because of the moderate effects of UVBR, as described above. The results showed similar trends in abundance and biomass under warming alone and under warming plus increased UVBR for the majority of planktonic organisms studied here. Therefore, the Mediterranean plankton food web during spring would respond more strongly to future expected warming than to future increases in UVBR.

The experiment described here was of relatively short duration $(10 \mathrm{~d})$. Therefore, the validity and robustness of our findings with respect to future global changes may be questioned. This study was designed to elucidate potential mechanisms involved in the functioning of the microbial plankton food web under warming and increased UVBR. A 10-d period corresponds to several generations of microorganisms, especially in relatively warm waters like those of the Mediterranean. Thus, this short duration is sufficient to highlight potential biologically mediated feedback mechanisms, such as trophic cascade effects (Petchey et al. 1999). Further experimental studies in different marine regions and seasons, taking into account local plankton community structures and physico-chemical conditions, will be necessary to elucidate how global changes will generally or specifically affect the functioning of the marine plankton food web and whether temperature-mediated trophic cascades are a general rule.

The present experiment clearly shows that increased water temperature alters the functioning of the plankton food web because it increases net oxygen production, essentially through an increase in gross oxygen production. On the contrary, warming has no significant effects on community respiration. This result contrasts with those of previous studies that have shown a significant increase in microbial respiration under warming (Vazquez-Dominguez et al. 2007). The lack of a clear increase in respiration under the increased temperatures observed here is probably caused by the negative indirect effect of warming, via cascading effect, on the heterotrophic bacterial community, which generally accounts for most of the community respiration (Rivkin and Legendre 2001). It has been previously suggested that warming drives the balance in favor of respiration, consequently increasing $\mathrm{CO}_{2}$ production by the microbial community and resulting in oceanic $\mathrm{CO}_{2}$ release (VazquezDominguez et al. 2007; Wohlers et al. 2009). However, we do not observe a balance in favor of respiration, indicating that in relatively productive warm waters (such as Mediterranean coastal waters during spring), increasing temperature finally can favor net oxygen production (autotrophic $\mathrm{O}_{2}$ production) instead of respiration.
Our study shows that heterotrophs respond rapidly to warming. This result is consistent with the metabolic theory of ecology (Brown et al. 2004), which predicts a strong temperature dependence of heterotrophic metabolism compared to autotrophic metabolism. Although testing our data within the framework of the metabolic theory of ecology is not the purpose of this article, and although we did not measure specific heterotrophic activity, we point out the potential applicability of this theory to understanding the functioning of marine and terrestrial ecosystems under global warming, as suggested previously (LopezUrrutia and Moran 2007; Lopez-Urrutia 2008). Further studies should test this unifying theory by considering resource limitation and organismal interactions such as predation to better evaluate biological responses to different global change scenarios.

In conclusion, the study presented here shows that the spring Mediterranean plankton community might respond more to future expected warming conditions than to future expected UVBR increases. In particular, warming can affect biological interactions in the plankton food web, inducing trophic cascades. Our results demonstrate the need to consider the responses of the entire food web and interactions therein rather than those of separate compartments to describe and predict the complex and sometimes counterintuitive responses of plankton to global changes.

\section{Acknowledgments}

We thank numerous students from Montpellier 2 and AixMarseille Universities for performing analyses and helping with the experiment. We thank C. Bouvier, M. Bouvy, J.-P. Torreton, and R. De Wit for their support during the mesocosm experiment and B. Charriere, D. Sarno, R. Sempéré, and T. Sime-Ngando for help with analyses. We are grateful to Y. Vergne for field assistance. This study is part of the project "Effects of climate change on marine pelagic food webs: Ultraviolet and temperature effects," supported by the French National Program on Coastal Environments (PNEC-Chantier Lagunes Mediterraéennes) and Groupement de Recherche (GDR) 2476 Réseaux Trophiques Aquatiques. The experimental platform MEDIMEER was founded by Unité Mixte de Recherche 5119 Ecosystèmes Lagunaires, Centre National de la Recherche Scientifique-Institut National Ecologie et Environnement, Institut Fédératif de Recherche 129 Armand Sabatier, GDR 2476 Réseaux Trophiques Aquatiques, and Région Languedoc-Roussillon.

\section{References}

Beaugrand, G., K. Brander, J. Lindley, S. Souissi, and P. Reid. 2003. Plankton effect on cod recruitment in the North Sea. Nature 426: 661-664, doi:10.1038/nature02164

Beisner, B., E. McCauley, and F. Wrona. 1997. The influence of temperature and food chain length on plankton predator-prey dynamics. Can. J. Fish. Aquat. Sci. 54: 586-595, doi:10.1139/ cjfas-54-3-586

Bоотн, B. C. 1993. Estimating cell concentration and biomass of autotrophic plankton using microscopy, p. 199-205. In P. F. Kemp, B. F. Sherr, E. B. Sherr, and J. J. Cole [eds.], Handbook of methods in aquatic microbial ecology. Lewis.

Brown, J., J. Gillooly, A. Allen, V. Savage, and G. West. 2004. Toward a metabolic theory of ecology. Ecology 85: 1771-1789, doi:10.1890/03-9000 
Caron, D., E. Lim, G. Miceli, J. Waterbury, and F. Valois. 1991. Grazing and utilization of chroococcoid cyanobacteria and heterotrophic bacteria by protozoa in laboratory cultures and a coastal plankton community. Mar. Ecol. Prog. Ser. 76: 205-217, doi:10.3354/meps076205

CARritt, D., AND J. CARPEnTER. 1966. Comparison and evaluation of currently employed modifications of the Winkler method for determining dissolved oxygen in sea-water; A NASCO report. J. Mar. Res. 24: 286-318.

Chen, F., J. Lu, B. Binder, Y. Liu, and R. Hodson. 2001. Application of digital image analysis and flow cytometry to enumerate marine viruses stained with SYBR gold. Appl. Environ. Microbiol. 67: 539-545, doi:10.1128/AEM.67.2.539-545. 2001

Christensen, M., M. Graham, R. Vinebrooke, D. Findlay, M. Paterson, AND M. Turner. 2006. Multiple anthropogenic stressors cause ecological surprises in boreal lakes. Glob. Change Biol. 12: 2316-2322, doi:10.1111/j.1365-2486. 2006.01257.x

Costanza, R., And others. 1997. The value of the world's ecosystem services and natural capital. Nature 387: 253-260, doi: $10.1038 / 387253 a 0$

Davis, A., J. Lawton, B. Shorrocks, and L. Jenkinson. 1998. Individualistic species responses invalidate simple physiological models of community dynamics under global environmental change. J. Anim. Ecol. 67: 600-612, doi:10.1046/ j.1365-2656.1998.00223.x

Doyle, S., J. Saros, and C. Williamson. 2005. Interactive effects of temperature and nutrient limitation on the response of alpine phytoplankton growth to ultraviolet radiation. Limnol. Oceanogr. 50: 1362-1367, doi:10.4319/1o.2005.50.5.1362

Edwards, M., and A. Richardson. 2004. Impact of climate change on marine pelagic phenology and trophic mismatch. Nature 430: 881-884, doi:10.1038/nature02808

Eppley, R. 1972. Temperature and phytoplankton growth in the sea. Fish. Bull. 70: 1063-1085.

Hargrave, C., K. Gary, and S. Rosado. 2009. Potential effects of elevated atmospheric carbon dioxide on benthic autotrophs and consumers in stream ecosystems: A test using experimental stream mesocosms. Glob. Change Biol. 15: 2779-2790, doi:10.1111/j.1365-2486.2009.01897.x

Hart, R., AND I. McLaren. 1978. Temperature-acclimation and other influences on embryonic duration in copepod Pseudocalanus. Mar. Biol. 45: 23-30, doi:10.1007/BF00388974

Intergovernmental Panel on Climate Change (IPCC). 2007. Climate Change 2007: The physical science basis contribution of Working Group I to the fourth assessment report of the Intergovernmental Panel on Climate Change. Cambridge Univ. Press.

KorolefF, F. 1983. Determination of ammonia, p. 150-157. In K. Grasshoff [ed.], Methods of seawater analysis. Verlag Chemie.

Larsen, P., And H. RiIsgard. 2009. Viscosity and not biological mechanisms often controls the effects of temperature on ciliary activity and swimming velocity of small aquatic organisms. J. Exp. Mar. Biol. Ecol. 381: 67-73, doi:10.1016/ j.jembe.2009.09.021

Latasa, M., X. Moran, R. Scharek, and M. Estrada. 2005. Estimating the carbon flux through main phytoplankton groups in the northwestern Mediterranean. Limnol. Oceanogr. 50: 1447-1458, doi:10.4319/1o.2005.50.5.1447

Lopez-Urrutia, A. 2008. The metabolic theory of ecology and algal bloom formation. Limnol. Oceanogr. 53: 2046-2047.

- AND X. MoRan. 2007. Resource limitation of bacterial production distorts the temperature dependence of oceanic carbon cycling. Ecology 88: 817-822, doi:10.1890/06-1641
MacFadyen, E., C. Williamson, G. Grad, M. Lowery, W. Jeffrey, AND D. Mitchell. 2004. Molecular response to climate change: Temperature dependence of UV-induced DNA damage and repair in the freshwater crustacean Daphnia pulicaria. Glob. Change Biol. 10: 408-416, doi:10.1111/j.1529-8817.2003.00750.x

Marie, D., F. Partensky, S. Jacquet, and D. Vaulot. 1997. Enumeration and cell cycle analysis of natural populations of marine picoplankton by flow cytometry using the nucleic acid stain SYBR green I. Appl. Environ. Microbiol. 63: 186193.

Mostajir, B., AND others. 1999. Experimental test of the effect of ultraviolet-B radiation in a planktonic community. Limnol. Oceanogr. 44: 586-596, doi:10.4319/1o.1999.44.3.0586

Neale, P., R. Davis, and J. Cullen. 1998. Interactive effects of ozone depletion and vertical mixing on photosynthesis of Antarctic phytoplankton. Nature 392: 585-589, doi:10.1038/ 33374

Nouguier, J., B. Mostajir, E. Le Floc’h, and F. Vidussi. 2007. An automatically operated system for simulating global change temperature and ultraviolet $\mathrm{B}$ radiation increases: Application to the study of aquatic ecosystem responses in mesocosm experiments. Limnol. Oceanogr.: Methods 5: 269-279.

Petchey, O., P. McPhearson, T. Casey, and P. Morin. 1999. Environmental warming alters food-web structure and ecosystem function. Nature 402: 69-72, doi:10.1038/47023

Pomeroy, L., AND W. Wiebe. 2001. Temperature and substrates as interactive limiting factors for marine heterotrophic bacteria. Aquat. Microb. Ecol. 23: 187-204, doi:10.3354/ame023187

Portner, H., And A. Farrell. 2008. Physiology and climate change. Science 322: 690-692, doi:10.1126/science.1163156

Putt, M., And D. Stoecker. 1989. An experimentally determined carbon-volume ratio for marine oligotrichous ciliates from estuarine and coastal water. Limnol. Oceanogr. 34: 1097-1103, doi:10.4319/1o.1989.34.6.1097

Reuder, J., M. Dameris, And P. Koepke. 2001. Future UV radiation in Central Europe modelled from ozone scenarios. J. Photochem. Photobiol. B Biol. 61: 94-105, doi:10.1016/ S1011-1344(01)00143-9

RiebeSELl, U., AND OTHERS. 2007. Enhanced biological carbon consumption in a high $\mathrm{CO}_{2}$ ocean. Nature 450: 545-548, doi:10.1038/nature 06267

Rivkin, R., AND L. LegendRe. 2001. Biogenic carbon cycling in the upper ocean: Effects of microbial respiration. Science 291: 2398-2400, doi:10.1126/science.291.5512.2398

Rose, J., And D. CARon. 2007. Does low temperature constrain the growth rates of heterotrophic protists? Evidence and implications for algal blooms in cold waters. Limnol. Oceanogr. 52: 886-895, doi:10.4319/1o.2007.52.2.0886

Rose, M. 1933. Faune de France. Office central de Faunistique, Paris. [French fauna.]

Sime-Ngando, T., M. Gosselin, S. Roy, and J-P. Chanut. 1995. Significance of planktonic ciliated protozoa in the lower St Lawrence Estuary: Comparison with bacterial, phytoplankton and particulate organic carbon. Aquat. Microb. Ecol. 9: 243-258, doi:10.3354/ame009243

SommarugA, R. 2003. UVR and its effects on species interactions, p. 487-508. In E. W. Helbling and H. Zagarese [eds.], UV effects in aquatic organisms and ecosystems. The Royal Society of Chemistry.

- J. Hofer, L. Alonso-Saez, and J. Gasol. 2005. Differential sunlight sensitivity of picophytoplankton from surface Mediterranean coastal waters. Appl. Environ. Microbiol. 71: 2154-2157, doi:10.1128/AEM.71.4.2154-2157.2005 
Sommer, U., And K. Lengfellner. 2008. Climate change and the timing, magnitude, and composition of the phytoplankton spring bloom. Glob. Change Biol. 14: 1199-1208, doi:10.1111/ j.1365-2486.2008.01571.x

Strecker, A., T. Cobb, and R. Vinebrooke. 2004. Effects of experimental greenhouse warming on phytoplankton and zooplankton communities in fishless alpine ponds. Limnol. Oceanogr. 49: 1182-1190, doi:10.4319/lo.2004.49.4.1182

Treguer, P., And P. Le Corre. 1975. Manuel d'analyse des sels nutritifs dans l'eau de mer: Utilisation de l'Autoanalyzer II Technicon, 2nd ed. Laboratoire d'Oceanographie chimique Univ. de Bretagne Occidentale. [Textbook of nutrient analysis in marine water: Utilization of the Technicon Autoanalyzer II.]

Vazquez-Dominguez, E., D. Vaque, and J. Gasol. 2007. Ocean warming enhances respiration and carbon demand of coastal microbial plankton. Glob. Change Biol. 13: 1327-1334, doi:10.1111/j.1365-2486.2007.01377.x

Vincent, W., AND S. Roy. 1993. Solar ultraviolet-B radiation and aquatic primary production: Damage protection and recovery. Environ. Rev. 1: 1-12.

Vinebrooke, R., K. Cottingham, J. Norberg, M. Scheffer, S. Dodson, S. Maberly, And U. Sommer. 2004. Impacts of multiple stressors on biodiversity and ecosystem functioning: The role of species co-tolerance. Oikos 104: 451-457, doi:10.1111/j.0030-1299.2004.13255.x

Walther, G., AND others. 2002. Ecological responses to recent climate change. Nature 416: 389-395, doi:10.1038/416389a

Weatherhead, E., AND S. Andersen. 2006. The search for a sign of recovery of ozone layer. Nature 441: 39-45, doi:10.1038/ nature 04746
Weitere, M., J. Dahlmann, C. Viergutz, and H. Arndt. 2008 Differential grazer-mediated effects of high summer temperatures on pico- and nanoplankton communities. Limnol. Oceanogr. 53: 477-486.

Williamson, C., G. Grad, H. De Lange, S. Gilroy, and D. KARAPElou. 2002. Temperature-dependent ultraviolet responses in zooplankton: Implications of climate change. Limnol. Oceanogr. 47: 1844-1848, doi:10.4319/lo.2002. 47.6.1844

Wohlers, J., AND others. 2009. Changes in biogenic carbon flow in response to sea surface warming. Proc. Natl. Acad. Sci. USA 106: 7067-7072, doi:10.1073/pnas.0812743106

World Meteorological Organization (WMO). 2007. Scientific assessment of ozone depletion: 2006. Global Ozone Research and Monitoring Project-Report No. 50.

Zapata, M., F. Rodriguez, and J. Garrido. 2000. Separation of chlorophylls and carotenoids from marine phytoplankton: A new HPLC method using a reversed phase C-8 column and pyridine-containing mobile phases. Mar. Ecol. Prog. Ser. 195: 29-45, doi:10.3354/meps195029

Associate editor: Wade W. Jeffrey

Received: 22 February 2010

Accepted: 19 August 2010

Amended: 07 October 2010 